revista ANTHROPOLÓGICAS

Ano 23, 30(2): 91-119, 2019

\title{
Inimigos, Jaguares e Espíritos: os outros e suas transformações
}

Marcel Mano

O artigo possui como mote as descrições históricas de sepultamentos indígenas em urnas cerâmicas, muitas das quais são musealizadas, e pretende, a partir de uma leitura antropológica das mesmas, associá-las ao universo das trocas negativas ou predatórias que os grupos humanos mantêm com o mundo exterior das alteridades. Com base numa aproximação etnológica com dados históricos e etnográficos, o artigo dialoga e problematiza dois pressupostos. $\mathrm{O}$ da hipótese de as urnas estarem relacionadas ao universo antropofágico-guerreiro descrita pelos cronistas entre os Tupinambá e Guarani; e o modelo de diferenciação Tupi e Jê centrado na dicotomia centrífugo x centrípeto. Para isso, apresenta o enterramento em urnas como código dentro de um grupo mais amplo de transformações que levam, em diferentes sociedades ameríndias, do interior ao exterior e vice-versa, e cujos processos de tradução são resultado tanto de um pensamento classificatório quanto de uma prática venatória.

Sepultamentos, Grupos Jê - 'Cayapó', Identidades e alteridades, Guerra e antropofagia, Práxis da caça.

A inumação em vasos cerâmicos - igaçabas - é bem conhecida na etnologia e arqueologia indígena no Brasil. Associada a sepultamentos primários e secundários ela ocorre em diversas áreas e é descrita historicamente entre populações indígenas culturalmente diferentes entre si. Para as áreas de ocupação histórica dos grupos Tupinambá

a Professor Associado do Programa de Pós-Graduação em Ciências Sociais e do Programa de Pós-Graduação em História (UFU). Email: marcelmano@ufu.br. 
e Guarani já foi sugerido (Carvalho 1983, 1999) que o sepultamento primário em urnas descrito nas fontes documentais pode estar em relação ao complexo antropofágico-guerreiro. A julgar pelas concepções que Viveiros de Castro (1986:516-520) vislumbrou entre os Araweté - grupo Tupi da Amazônia: a de que existe no xamanismo uma forma cosmológica de antropofagia, é possível reforçar a associação desta com a urna; pois que uma metafisica canibal também sugere que as urnas - panelas - poderiam servir como duplo modo de transformação do morto - matador em vida. Primeiro como metáfora do cozimento para ser servido no post mortem ao festim dos deuses canibais; e em sequência como homologia porque ao ser devorado transforma-se também em imortal.

Apesar da coerência analógica esse sistema precisa ainda ser testado em outra realidade: a existência de informações documentais de urnas com sepultamentos em áreas de ocupação histórica de grupos dos Jê, conhecidos como 'Cayapó' ${ }^{1}$, nas regiões dos atuais sul de Goiás, Triângulo Mineiro e norte de São Paulo. Se considerarmos que os modelos para pensar a etnologia dos povos indígenas no Brasil (Cunha \& Castro 1985; Fausto 2001; Gordon 2006) propõem uma diferenciação entre Tupi e Jê que oscila respectivamente entre grupos centrífugos x centrípetos, e grupos de predação canibal x predação cerimonial, temos um problema que incide sobre uma escolha. Ou a hipótese da associação dos sepultamentos em urnas com a antropofagia encontra aqui certos limites, ou, ao contrário, os limites se encontram no modelo de diferenciação Jê - Tupi.

Em face desse impasse, este ensaio quer relacionar a incidência histórica de urnas mortuárias em áreas de ocupação dos Jê com as notícias dos primeiros contatos desses grupos, documentalmente conhecidos como 'Cayapó'. A tentativa é a de encontrar nas relações com o mundo exterior das alteridades um fundo histórico que possa servir para iluminar as escolhas. Tal como é possível depreender das fontes, grupos desses índios foram, no século XVIII, expostos a um cenário de intensos contatos com diferentes outros. Além dos grupos 
indígenas autóctones; mestiços, homens livres pobres, autoridades coloniais, índios escravos, negros escravos, negros fugidos, entre outros, passaram a compor o mundo exterior a esses grupos. Embora não tenham sido unânimes as formas de tratamento das diversidades (porque dependeram dos sujeitos, dos contextos, dos signos e dos interesses envolvidos) esses grupos 'Cayapó' fizeram da guerra um dos seus principais modos relacionais e simbólicos de relação com algumas de suas alteridades, e talvez seja este o aspecto fulcral. Afinal, se a existência de analogias do sepultamento em urnas em áreas dos Tupinambá e Guarani históricos está em uma determinada associação com rituais de predação de corpos descritos pelos cronistas; alguns episódios que se desenvolveram durante as guerras nas primeiras décadas dos contatos dos grupos Jê talvez possam iluminar nossas opções.

\section{As urnas mortuárias.}

Nas áreas do litoral atlântico ocupadas historicamente pelos Tupinambá as urnas foram descritas como igaçabas de base convexa e tampa invertida, e pintada de "[...] desenhos de cor marrom escuro [...] em engobo branco, [...] as duas linhas que separam as três faixas do ombro escalonado são vermelhas" (Pereira et al 1982:6-7). Esteticamente são cerâmicas de decoração policrômica com traços lineares sobre fundo engobado. Nas áreas da bacia Paraná-Paraguaia ocupada pelos Guarani históricos, as urnas apresentavam decoração corrugada e as tampas desenhos geométricos policrômicos. A decoração corrugada foi descrita como "escultura em relevo em forma de escama de peixe" coberta com "tampas ornamentadas com motivos geométricos intricados", com faixas largas em preto e vermelho e, ocasionalmente, combinados com ornamentação pontular arredondada e virgular (Godoy 1974:171-173).

Em ambas as áreas históricas: a dos Tupinambá e a dos Guarani, os cronistas dos séculos XVI e XVII (Cardim 1980:94; Souza 1964:582) descreveram o uso mortuário desses sofisticados vasos cerâmicos. Foram algumas dessas descrições que permitiram Carvalho $(1983,1999)$ associar as urnas ao complexo antropofágico-guerreiro. 
Nos relatos históricos, os termos usados para as urnas são cuias, vasos, panelas ou potes. Gabriel Soares de Souza escreveu: "[...] mettem-no em cócoras, atados os joelhos com a barriga, em um pote em que elle caiba [...]" (1964:582). Cardim mencionou que "[...] assentado o metem em um pote [...]" (1980:94). Entre os Chiriguanos, Nordenskiöld descreveu "[...] o costume de a viúva partir uma yambui (vaso para chicha) ao meio a fim de enterrar o marido [...]" (apud Carvalho 1999:9). Métraux, reproduzindo Thevet, afirmou que "[...] metem-no em um grande vaso de barro, cobrindo-o com a gamela onde o defunto costumava lavar-se [...]" (1979:07). As urnas - igaçaba - e tampas - alguidares - eram, então, recipientes com finalidades práticas e culinárias, tais como potes para a água e cocção de alimentos. Os alguidares possuíam formato próprio para o preparo da farinha de mandioca e o uso como tigelas, e as igaçabas, com suas bordas mais largas que os fundos, eram recipientes para alimentos sólidos e líquidos, entre os quais as bebidas fermentadas (cauim ou chicha) consumidas em grandes quantidades durante os rituais coletivos, entre os quais o antropofágico. De acordo ainda com as descrições documentais, o período que antecedia o sacrifício do prisioneiro era particularmente destinado à fabricação de vasos e alguidares ricamente decorados. Cardim escreveu que "determinado o tempo em que há de morrer, começam as mulheres a fazer louça, a saber: panellas, alguidares, potes para vinhos, tão grandes que um levará uma pipa [...]" (1980:96), informação corroborada com Métraux em sua síntese histórica da 'religião dos tupinambás':

"As mulheres encarregavam-se da fabricação de numerosos vasos de formas e dimensões diversas, que decoravam com cuidado todo especial. Determinados potes serviam para guardar as bebidas fermentadas; outros a tinta com a qual o prisioneiro devia ser pintado. Certas moças estavam encarregadas de preparar o cauim" (Métraux 1979:124).

Durante os rituais os 'potes grandes' guardavam as bebidas, e os alguidares, usados para o preparo da farinha de mandioca e do cauim, recebiam também as entranhas do prisioneiro sacrificado. Associadas 
à morte do inimigo essas cerâmicas rituais eram, depois, usadas como urnas e tampas mortuárias para corpos de amigos e parentes. Dessa associação resultou uma primeira aproximação entre a urna e o ritual antropofágico. Uma outra associação foi constatada entre as pinturas rituais do sacrificador, do sacrificado e do instrumento - o ibirapema, semelhantes às das cerâmicas rituais e mortuárias. A decoração esmerada que apareciam nas bordas dos grandes vasos e no interior dos alguidares se repetia no ibirapema e na testa do prisioneiro a ser morto, pintado "de preto com pinturas galantes [...] e da mesma maneira que eles têm pintado o rosto (do prisioneiro), o está também a espada [...]" (Cardim 1980:98). E, finalmente, uma terceira associação foi entre o morto inumado com o inimigo devorado. Esse mesmo cronista mencionou que os Tupinambá lavavam o defunto, e o "pintão muito galante, como pintão os contrários” (Cardim1980:94), sugerindo a pintura que era feita no inimigo devorado nos rituais antropofágicos; e Souza (1964:582) escreveu que untavam com mel o corpo do defunto antes de colocá-lo na urna.

Ao considerar que a cerâmica mortuária serviu antes em rituais antropofágicos, que o morto era condimentado e recebia pintura corporal semelhante ao do inimigo canibalizado, o sepultamento em urnas parece ter relações claras com o inimigo devorado pelos deuses na aldeia dos mortos. Esse estado de coisas levou Carvalho (1983, 1999) a formular a tese de que a sepultura do cadáver diretamente numa urna devia corresponder ao simbolismo antropofágico guerreiro. Ao chefe ou guerreiro que não terminasse seus dias sacrificado pelos inimigos, reservava-se uma inumação num vaso de cauim ou chicha para ele mesmo ser devorado pelos deuses canibais (Castro 1986).

Acontece, porém, que o sepultamento primário em urnas também ocorre fora das áreas de ocupação histórica dos Tupinambá e Guarani, e em urnas confeccionadas sem decoração, em estética escura e lisa ${ }^{2}$. Elas são particularmente descritas entre povos indígenas das regiões interioranas do Nordeste e dos Planaltos Central e Meridional brasileiros. 
$\mathrm{Na}$ parte norte nordeste desse último planalto, região que corresponde aos atuais sul de Goiás, Triângulo Mineiro e norte de São Paulo, essas urnas foram encontradas em grande profusão na década de 1960 no município de Cachoeira Dourada durante construção de Usina Hidrelétrica no Rio Paranaíba, divisa dos estados de Minas Gerais e Goiás (Silva 2015:57). Em escavações arqueológicas às margens desse mesmo rio:

"Foi coletada uma urna funerária, lisa, grande, associada a uma tigela, com sepultamento de um indivíduo adulto, em posição fetal, na área da aldeia, mas fora dos espaços habitacionais. A escavação desenvolvida no sítio Silva Serrote [...] detectou peças cerâmicas inteiras e um sepultamento em urna de cerâmica lisa em posição fetal. A cerâmica coletada corresponde a dois tipos: - o LISO, representativo e predominante (com ausência de decoração) - e com ENGOBO, nas cores branca e preta" (Alves 1991:75).

Entre os documentos históricos foi o memorialista Hildebrando Pontes que se referiu a esses achados no Triângulo Mineiro, por toda a bacia do rio Grande e alto Paranaíba.

"Urnas funerárias, muitas, têm sido encontradas nas vizinhanças de Desemboque [...]. No município de Uberaba são encontradas em diversos lugares [...] e igaçabas têm sido encontradas nos ribeirões do Borá, Farinha Podre e Chapadão do rio Claro, município de Sacramento, fazenda do Lanhozo, ribeirão Corrente, Laranjeiras, Santa Gertrudes, Verissimo etc. de Uberaba; na Mata entre os ribeirões Santa Rosa, Dourados, distr. De Coromandel” (Pontes 1978:13-14).

Nos diversos relatos narrados por esse memorialista há a de uma urna desenterrada em abril de 1894 na região do Capão do Mico próximo a cidade de Araxá - MG, que ele indicou como 'urna funerária ou igaçaba encerrando a múmia de um cacique indígena'. Descrita em detalhes, revelou-se tratar de um sepultamento primário.

“[...]. Dentro, estava um corpo humano, verdadeiro espectro, de cócoras. [...] Era o cadáver de um índio velho, peito largo, rosto levemente triangular, maças do rosto salientes e quase imberbe. A pele, sobre os ossos, desenhava sua saliência, braços caídos ao longo do corpo; mãos abertas e secas; as pálpebras muito metidas dentro das 
cavidades vazias. No beiço inferior um pequeno furo onde foi introduzido um pedaço de osso. A pele, retraindo-se deixou a descoberto duas filas de dentes chatos [...]. Na cabeça, cingindo-a um acanguape ou cocar de penas de cores várias salientando-se a vermelha; no pescoço um rosário de dentes e ossos (aiupa), distintivo dos guerreiros. $\mathrm{Na}$ cintura uma tanga de penas vistosas e nos artelhos enfeites de penas e uma espécie de chocalho, que produzem sons agudos e ásperos. Dentro havia, além de um arco e trinta e sete flechas, uma aljava de couro de cutia, uma rede e duas cuias cobertas de bordados extravagantes [...]" (Pontes 1978:14-15).

Essas diversas descrições efetivamente indicam nesta região a existência de inúmeros sepultamentos primários em posição fetal em urnas periformes e lisas. E embora ainda sejam desconhecidas descrições históricas dos rituais funerários que acompanhavam esses enterramentos, é possível usar a documentação histórica para contextualizá-los. Mas neste caso, e para não cairmos nos erros que estamos tentando evitar, a documentação histórica só pode ter validade se dados arqueológicos e documentais forem temporalmente coincidentes. Felizmente, neste caso, os dados convergem.

Desde a década de 1980 programas arqueológicos sistemáticos na bacia do médio rio Paranaíba têm insistido para uma ocupação prolongada de populações agricultoras ceramistas datadas pelos menos desde o século XII (Alves 2013:105), às quais estavam associados a inumação em urnas. Mais recentemente, a escavação dos sítios Inhazinha e Rodrigues Furtado no município de Perdizes MG (Magalhães 2015) revelou zonas de ocupações datadas entre o último quarto do século XVIII e o primeiro do XIX (entre 1784 e 1825). A considerar a datação e o fato dos artefatos indígenas apresentarem influências dos não-índios, como o emprego de base plana (Magalhães 2015:272), está claro que se trata de ocupações de povos agricultores e ceramistas históricos. $\mathrm{O}$ período e o local dessas ocupações (o vale do rio Paranaíba) coincidem com dados da documentação histórica que, com o uso do termo 'Cayapó', identificou os grupos Jê nessa região. 
A julgar pela coincidência espaço-temporal, as descrições históricas que se fizeram desses grupos durante o contato podem contribuir na construção de uma interpretação acerca da incidência de urnas com sepultamento primário nessas áreas. Afinal, há indícios documentais para confirmar ou descartar a associação da urna com a antropofagia? e/ou há indícios para confirmar ou descartar a funcionalidade da oposição etnológica Jê - Tupi?

\section{Guerras e predação}

A primeira notícia histórica do termo 'Cayapó' data de 1723. Nesse ano Antonio Pires de Campos embarcou em expedição pelo rio Tietê. Ao cruzar sua foz, subiu o curso do rio Paraná e entrou no rio Paranaíba, atingindo as regiões dos atuais sul de Goiás e Triângulo Mineiro. Nesse local os 'Cayapó' foram mencionados em grande extensão territorial: "o gentio chamado Caiapó [...] é de aldeias, e povoa muita terra por ser muita gente, cada aldeia com seu cacique" (Campos 1976:181). Desde essa primeira notícia, os documentos históricos insistiram durante quase dois séculos em definir as bacias do Paranaíba e Grande como área densamente povoada por grupos 'Cayapó'.

No entanto é preciso cautela. Primeiro porque um exame de parte da documentação histórica revela que a região era área ocupada por outros grupos Jê, tais como os Akroá, Akwén, Araxá, Xakriabá e Xavante ${ }^{3}$. E segundo porque 'Cayapó' não é uma etnotaxinomia. É um exônimo, termo de origem tupi-guarani para definir grupos Jê; e de significado depreciativo para definir humanos - "como macacos" (Turner 1992:311). Isso implica pensar que 'Cayapó' foi uma construção colonial, termo genérico aplicado indistintamente. Por isso, e tal como já advertia um historiador do século XIX, "estava o nome 'Cayapós' tão vulgarizado n'outro tempo nas províncias de S. Paulo, Goyaz e Minas, que se dava [...] ao índio que ali apparrecesse qualquer que fosse a sua raça” (Oliveira 1861:492). Deste ponto de vista 'Cayapó' é aqui usado na sua acepção histórica, como termo generalizante para diferentes grupos pertencentes à família linguística Jê do 
Tronco Macro-Jê descritos nos séculos XVIII e XIX nos atuais sul de Goiás, Triângulo Mineiro e norte de São Paulo.

$\mathrm{Na}$ documentação a eles referente, além da constatação de que ocupavam essa área de forma densa e contínua, outra característica persistente desde o primeiro registro foi a guerra. Naquele primeiro contato, após descrever as aldeias e as lavouras, Campos escreveu: "[...] e seu maior exercício é serem corsários de outros gentios de várias nações e prezarem-se muito entre eles a quem mais gente há de matar" (1976:182). Embora pareça não ter ocorrido nenhum incidente com a expedição desse sertanista, não tardou para que os documentos registrassem as continuas guerras, mortes, roubos, incêndios e ataques impetrados por esses grupos contra os não índios.

Em praticamente todas as ocasiões em que foram mencionados durante os primeiros contatos, esses indígenas estavam numa constante estratégia de predação de inimigos, corpos e bens. De acordo com os documentos eles matavam e roubavam os viajantes, atacavam os roceiros e os mineradores, queimavam sítios, matavam criações, escravos, homens, mulheres e crianças (D.I. $\left.{ }^{4} 22: 185\right)$. As infindáveis e constantes evidencias dessas estratégias de guerra e pilhagem já foram discutidas em outras ocasiões (Mano 2011), e uma disposição diacrônica dos eventos mostrou uma estrutura da guerra contra os não índios: ataques rápidos e certeiros durante os quais matavam o maior número de inimigos e se apropriavam de seus bens, tais como plantas, armas de fogo, ferramentas de metal e objetos exóticos.

Eram, por isso, guerras de predação; tema que nos leva a uma outra questão que desde o primeiro relato histórico esteve associada aos 'Cayapó': a antropofagia. Em 1723 quando Campos concluiu sua menção à guerra ele completou: "[...] prezarem-se muito entre eles a quem mais gente há de matar, sem mais interesse que de comerem os seus mortos, por gostarem muito de carne humana" (1976:181-182); tônica repetida em outros documentos do período, "porque sempre que tem ocasião se sustentam de carne humana” (AHU-ACL-CU. 008-cx.2-d.465). 
Mas aqui novamente é preciso cautela. Ao contrário do que ocorre com as informações documentais oriundas das áreas de ocupação dos Tupinambá e Guarani, não há testemunha ocular que tenha descrito a devoração ritual entre esses grupos dos Jê. Em todos os casos a antropofagia lhes foi imputada de maneira indireta. A ausência de informação histórica precisa, associada ao conhecimento etnográfico dos Jê, já fez sugerir que se tratou aí de mais uma das 'alegorias da colonização’. Ao considerar o cenário de disputas, interesses conflitantes e intensos conflitos em que se deram os contatos, do ponto de vista dos não índios e, portanto, dos documentos, os índios do sertão estavam sendo retratados como feras, e como tais identificados e tratados pela política indigenista do período ${ }^{5}$. A antropofagia foi talvez mais uma das justificativas para os não índios legitimarem seus discursos e ações contra os índios.

Do ponto de vista do tema que aqui se aborda, pensar a antropofagia como 'alegoria da colonização' parece afastar as relações entre o sepultamento primário em urnas e a predação canibal entre esses grupos dos Jê. Fosse isso, a nossa escolha já estaria feita e se tornaria inócua essa reflexão. Embora pareça sensato descartar a antropofagia, com base em algumas evidencias também parece ingênuo não supor que a morte infligida ao inimigo em batalha tenha sido, ela mesma, predação de corpos.

Desde aquele primeiro registro do termo 'Cayapó' a arma continuamente mencionada entre eles no XVIII é o porrete ou bilro: "[...] garrotes, que são de páu de quatro ou cinco palmos com uma grande cabeça bem feita, e tirada, com os quais fazem um tiro [...], e tão certo que nunca erram a cabeça; é a arma de que mais se fiam, e se prezam muito dela" (Campos 1976:182). Essa arma foi tão difundida ao longo das guerras dos Jê - 'Cayapó' que alguns autores (Monteiro 1994:63; Neme 1969:114-117) já levantaram a hipótese de no século XVII eles serem conhecidos como Bilreiros ou Ibirajara, "senhores do tacape" segundo Schaden (1954:397).

Como armas de guerra as bordunas estão claramente associadas ao esfacelamento do crânio do inimigo. Os ataques obviamente ge- 
ravam combates corpo-a-corpo com deflagração de golpes causadores de fraturas, mutilações e rompimento de crânios. Em seu sentido prático a borduna desempenhava na guerra 'Cayapó' o mesmo papel do ibirapema tupinambá, pois ambos, empunhados por guerreiros, abriam o crânio do oponente com um golpe forte e certeiro. Caído sem vida, o corpo poderia então ser manipulado. Embora raras, houve informações de ataques nos quais os 'Cayapó' foram acusados de matar escravos e de "[...] lhes raspar toda a carne do corpo deixandolhes só a cabeça” (AHU-ACL-CU-008, cx.1-doc.17). Ainda que essa narrativa possa ser ela mesma mais uma alegoria, ela tem correlatos precisos com certos mitos de grupos Jê -Kayapó nos quais um grupo de guerreiros, após matarem os inimigos "[...] retalharam seus corpos, partindo-os ao meio. Depois cortaram na floresta troncos delgados nos quais amarraram os cadáveres pelas mãos e pés, a fim de leva-los para casa” (Luckesh 1976:188-189). Por isso é pelo menos sensato pensar, pelas características das guerras com bordunas, que elas acarretavam, senão o descarne, a manipulação direta dos corpos, não só pela proximidade e intensidade do golpe, mas também pelo tipo de ferimento mortal. E a analogia poderia ainda se estender às pinturas corporais; pois se de um lado as pinturas rituais do sacrificador tupinambá foram simbolicamente associadas com as decorações das urnas e alguidares policrômicos, a pintura guerreira dos 'Cayapó', sempre negra, também pode estar em relação lógica com as urnas lisas e sem decoração mencionadas em suas áreas históricas de ocupação.

Esfacelar crânios, destruir corpos, matar criações, queimar plantações, casas e paióis "reduzindo tudo a cinzas, e levando os despojos” (AHU-ACL-CU-008, cx. 20, d. 1220), parece de fato não conter a devoração canibal. No entanto, uma predação sem consumação antropofágica não deixa de ser uma predação. As descrições das guerras dos Jê no XVIII apontam a manipulação de partes objetiváveis de seus inimigos por dois caminhos: o da predação de corpos em batalha, e o da apropriação de bens móveis. Assim, e pelo mesmo raciocínio, se por meio do ritual antropofágico o sacrificador 
tupinambá adquiria as virtudes do inimigo e ganhava nomes; na guerra 'Cayapó' os guerreiros aniquilavam corpos e adquiriam riquezas e bens de seus inimigos.

Esse fundo histórico parece sugerir que a guerra 'Cayapó', assim como a antropofagia tupinambá, foram portas de entrada e saída para o mundo exterior. Nesse sentido, é possível que seja essa predação e a abertura para o outro (da qual a antropofagia é apenas uma forma) o que permita pensar a associação simbólica entre guerra e os sepultamentos em urnas nas áreas de ocupação histórica de grupos Jê.

\section{Predação e produção}

Ao considerar as estratégias de guerra e pilhagem levadas a cabo por esses grupos durante os primeiros contatos, parece certo que eles se encontravam a um meio termo entre os sistemas Jê - Tupi definidos pela etnologia. Se "na predação [Jê] mebêngôkre a destruição física do inimigo pode ser dispensável" (Gordon 2006:99), as guerras dos Jê no XVIII aí não se encaixaram. Noutra direção, se encaminharam ao encontro dos sistemas amazônicos, para os quais "uma dimensão importante da guerra é a destruição de corpos ou, mais exatamente, da pessoa em seus constituintes materiais e imateriais" (Fausto 2001:328). Mas afastando-se do complexo antropofágico Tupinambá, os Jê - 'Cayapó' não chegaram também a se encaixar plenamente nesse sistema. Afinal, parece claro que não houve predação canibal; tanto quanto também é nítido que a predação não foi apenas cerimonial. Além disso, ao implicar na apropriação de virtudes e riquezas adquiridas no contato com as alteridades, a guerra funcionou como uma constante abertura para o mundo exterior e suspendeu também a rigidez do binômio Jê - centrípeto x Tupi - centrífugo para pensar os Jê no século XVIII.

Se neste caso as oposições da etnologia se tornaram inoperantes, decorre o fato da dicotomia entre sociedades centrípetas/predação cerimonial e centrífugas/predação canibal ser apenas modelo para pen- 
sar a realidade. $\mathrm{O}$ caso em pauta mostra como as sociedades empíricas podem ser compostas de combinações híbridas dos modelos, e isso reforça menos a oposição e mais a existência de um continuum de possiblidades entre polos dicotômicos. Vale, aqui, a mesma advertência de Lévi-Strauss sobre os equívocos de pensar o modelo de sociedades quentes e frias como fechado.

"[...]. Disse, escrevi, repeti centenas de vezes que nenhuma sociedade é absolutamente fria ou quente. Essas são noções teóricas que necessitamos para formular nossas hipóteses. As sociedades empíricas distribuem-se ao longo de uma linha em que nenhuma delas ocupa os pólos" (Lévi-Strauss \& Eribon 1990:160).

Situados a um ponto da linha entre os dois sistemas definidos pela etnologia, grupos dos Jê tornaram a predação de corpos e bens o modo operante de relações com as alteridades. Disso resulta a ideia de a urna estar em relação não apenas com a antropofagia, mas com as formas de consumação de partes objetiváveis dos inimigos. $\mathrm{O}$ inimigo devorado e o abatido no campo, ambos com os crânios esfacelados e suas riquezas e virtudes expropriadas, tornam a antropofagia e a guerra pontes por onde transitaram interesses e signos. Ou em outros termos, a destruição e apropriação de bens e riquezas do exterior esteve tanto para uma simbólica centrífuga da alteridade, quanto para a construção centrípeta de sociabilidades.

As guerras de predação e saque foram a oportunidade desses grupos em fazer aferir para o mundo interior bens simbólicos e materiais que se colocavam a serviço da produção social ${ }^{6}$. Ainda que não seja possível uma etnografia dos 'Cayapó' meridionais do XVIII, uma comparação com outros grupos da família dos Jê pode indicar algumas hipóteses. Em geral, nessas sociedades as guerras mantem um papel importante na organização dos principais rituais de iniciação masculina, tais como o ritual de nominação, de perfuração de lábios e orelhas e de escarificação, que denotam a produção social da pessoa.

"Entre os [Kayapó] XIKRIN é considerado homem tão-somente aquele que tiver tomado parte numa expedição guerreira e morto 
um inimigo, Assuriní, Parakanã, Gorotire ou um cristão, embora este não seja tão apreciado." (Vidal 1977:155).

Marcas corporais, reconhecimento social e status é o que ganhava o guerreiro Jê com a predação do mundo exterior. Talvez por isso é que durante os contatos eles nunca desperdiçaram as oportunidades de afirmarem-se, na guerra e na predação, como homens fortes e bravos. Mas as guerras não lhes forneciam apenas bens simbólicos como a bravura, a coragem e a valentia. Eles vinham também, como vimos, em forma de bens materiais móveis. De certo, nunca saberemos como esses bens circularam no interior dessas comunidades, mas as inferências com outros grupos Jê podem também nos ajudar.

Como se sabe, entre grupos Jê Kayapó (Xikrin Mebêngôkre) há dois tipos de transmissão de riquezas. Um deles, horizontal, é representado pela posse coletiva da pintura corporal. $O$ outro, vertical, diz respeito à posse exclusiva de riquezas que envolvem atributos sociais distintivos como propriedades de "clãs" (Vidal 2001:212-213) e/ou 'matricasas' (Lea 2012). Tradicionalmente representado pelos adornos plumários e nomes bonitos, esses bens são transmitidos por herança e por confirmação ritual. Apesar de representar um sistema dual, coexistem entre os Jê Xikrin Mebêngôkre formas de circulação e transmissão frequente de bens, inclusive os adquiridos no contato com os não índios (Gordon 2006), como parte mais ampla de uma rede de sociabilidades por meio das quais se firmam alianças formais e potenciais e reforçam-se relações entre parentes afins e consanguíneos. Machados de aço, armas de fogo e objetos manufaturados aferidos durante as guerras no século XVIII poderiam, então, colocar em ação processos de aliança e de produção de parentesco, servindo como signos sociais que se transmitiam e circulavam entre parentes, amigos e aliados.

Por isso a apropriação interna de bens e riquezas poderia estar para a esfera da produção social. Uma produção do interior que foi, como vimos, predatória, pois se realizou na destruição do exterior. Dessa ótica, as pontes entre o interior e o exterior construídas pelas guerras estiveram tanto para interesses pragmáticos da esfera produti- 
va, como para uma simbólica da alteridade. Afinal, as violências físicas que caracterizaram as guerras foram resultadas dos contatos entre grupos que se avaliavam e se percebiam como inimigos em algum grau.

Nas guerras parece certo que ao menos incialmente a simbólica da alteridade é sinônima da simbólica do inimigo, o outro representado como perigo e ameaça. E isso para ambos os lados, como o mostra a história dos contatos dos Jê 'Cayapó' meridionais. Do mesmo modo que os documentos pediam para "passar a espada, sem distinção nenhuma de sexo" (D.I. 22:168) e para matar "de dores os Cayapó, dos quaes trouxerão as cabeças a essa Villa” (AHE-GO-Livro 003), eles também relatavam que "o barbaro Gentio Cayapó assaltou com sua costumeira ferocidade" (AHU-ACL-CU-008-cx.2-d.179), "havendo-se com tão barbara crueldade que nem as crianças perdoam nem dão quartel a pessoa alguma" (D.I. 22:185). Ódio mutuamente nutrido, as guerras como pontes entre o interior e o exterior foram áreas de fronteiras onde se cruzaram identidades e diferenças, inclusão e exclusão. Ponto incerto do contato, essas fronteiras se expandiram e se retraíram, se sobrepuseram e se descolaram com base na dialética da percepção - ação, do interesse - signo, sendo por isso cambiantes como as pontes. Muito embora fluidas e maleáveis, sobretudo no início dos contatos as fronteiras existiram. Foram erguidas por coletivos sociais que se reconheceram no processo de estranhamento e em suas projeções da alteridade. Assim, o que e como da alteridade não indígena os 'Cayapó' meridionais destruíram e o que eles incorporaram fala também de quem destruiu e incorporou. Ao longo das primeiras décadas de contato as guerras 'Cayapó' moveram-se sempre na destruição e exclusão de corpos inimigos e na inclusão de seus bens materiais. Os não índios deviam figurar como criaturas revoltantes, mas inimigos poderosos. Seus objetos manufaturados, suas ferramentas de metal e suas armas de fogo deviam representar uma inigualável expressividade técnica e estética, e domínio de artes que os grupos indígenas não conseguiam imitar. Essas qualidades dos não-índios, vivenciadas durante os anos de contato, serviram para justificar uma forma de percepção, 
avaliação e ação na qual esses inimigos figuravam como criaturas desprezíveis - deviam ser mortas, mas poderosas.

Se no início dos contatos esse outro não índio foi interpretado como potencialmente perigoso e empiricamente poderoso, isso justificou o processo de destruição e incorporação. Nesse constante jogo de reconhecimento e estranhamento, de contrastes e diferenças, de distanciamentos e aproximações, os sistemas de classificações das alteridades levam a pontos delicados, como o dos limites entre interior e exterior, e os processos correlatos de domesticação e domínio das diferenças.

Se de fato as fronteiras e pontes entre o interior e o exterior foram maleáveis, fluidas e cambiantes, reconhecimento e estranhamento não foram pontos fixos eternos. Antes disso, foram rotacionais e, como tais, permitiram processos de inversão por meio das possiblidades de transformação ritual. Como a moderna etnografia hoje sabe, por meio desses processos inimigos e aliados, parentes e estranhos, vivos e mortos, animais e humanos não se separam por barreiras intransponíveis. Ao contrário, se metamorfoseiam e se intercambiam; ou nos termos do perspectivismo (Castro 1996), as categorias de identidade e alteridade são variáveis e contextuais, e exemplos disso já são bem conhecidos na etnologia indígena.

No caso da guerra que aqui nos interessa de perto, casos de inversão acontecem frequentemente associados à transformação do inimigo em aliado e vice-versa. Alguns exemplos da cosmologia de grupos Tupi mostram isso. Para os Tapirapé, estudados por Wagley (1977:243), os espíritos dos Kayapó mortos tornavam-se espíritos auxiliares dos xamãs e avisavam dos ataques dos Kayapó vivos. Entre os Mundurukú, as cabeças troféus arrancadas de seus inimigos eram ornadas e decoradas à imagem étnica Mundurukú (Menget 1993). E da mesma forma que a morte guerreira do inimigo o transformava em aliado, a morte do parente também operava sua transformação em inimigo; tal como ilustra a inumação em urna dos Tupinambá, na qual o morto recebia pintura corporal semelhante à do inimigo canibalizado. 
Para os grupos Jê, e em particular para os 'Cayapó' meridionais não há, como vimos, registros da predação dos corpos além do campo de batalha. Mas evidencias a respeito de raptos de jovens mulheres podem nos instruir acerca da domesticação da alteridade. Embora pouco relatado, grupos 'Cayapó' no século XVIII mencionados na região do atual Triangulo Mineiro, estavam em guerra com os Araxá: “[...] o gentio Caiapó tinha feito tal hostilidade aos gentios Arachás, que não só lhes fizera uma grande mortandade, mas depois lhes cativaram todas as mulheres e crianças" (AHU-ACL-CU-008-cx.2-d.465). E em uma etnografia dos Kayapó Xikrin, Vidal perguntou sobre o destino de mulheres raptadas de outros grupos indígenas: "Perguntei se pegavam essas mulheres para fins sexuais imediatos, disseram: 'Não, não sabem falar; primeiro amansar, falar e depois casar'” (1977:47). Se esses indícios estão corretos, nos grupos Jê a guerra de rapto de mulheres de outros grupos indígenas dá lugar ao processo de domesticação (amansar), assimilação (falar) e afinização (casar) da vítima.

Obviamente não se trata de predação canibal, mas, semelhante a essa, há uma inequívoca predação para a produção que implica, entre outros, na transformação do inimigo em parente e aliado. Se a urna mortuária está no contexto dessa predação produtiva, talvez então ela implique nas possibilidades de transformações simbólicas inversas: às que levam do parente vivo como aliado ao parente morto como inimigo, tal qual nos ilustram - como acima mencionado - as descrições históricas para os enterramentos primários em urnas nas áreas de ocupação histórica dos Tupinambá.

\section{Predação e práxis}

A maleabilidade das fronteiras entre o interior e o exterior não parece ser, no entanto, apenas resultado de um pensamento analógico, de um jogo estrutural de possibilidades de classificações, associações, inversões e transformações simbólicas. Ela parece ser também, simultaneamente, produto de uma prática venatória. Afinal, problemas de continuidade e descontinuidade entre o interior e o exterior também 
se colocam, na ação e no pensamento, entre o mundo humano e o extra-humano da natureza. Desde pelo menos o neolítico há de fato, em todos os grupos humanos, processos de domesticação e manipulação de espécies naturais, e processos de apropriação simbólica da natureza, seja por meio de classificações e nomeações, por criação de áreas pelo manejo, ou por transformação e controle ritual. Mas apesar dos constantes esforços técnicos e cognitivos, essa natureza domesticada convive com uma natureza indomada e hostil. Mais antiga que os homens, essa natureza é representada por forças produtivas que se desenvolvem independentemente da ação humana, cujo protótipo chave é o universo dos animais de caça. Dele os grupos indígenas também se apropriam simbólica e materialmente por meio de técnicas e conhecimentos definíveis como 'práxis da caça'.

Apesar das relações simbólicas entre homens e animais caçados serem bastante diversificadas nos diversos grupos ameríndios, há em todos uma realidade empírica: as condições materiais da caça consistem permanentemente na morte de um para dar vida ao outro. A esse tipo de relações entre o mundo humano e a natureza, Carvalho definiu como troca negativa, "como relações entre comunidade humana e o que nós chamamos de 'natureza' -o caçador dá morte ao animal” (2015:26-27), e à qual podemos incluir as relações beligerantes entre os grupos humanos, porque o guerreiro também dá morte ao inimigo. Como 'trocas negativas', guerra e caça são modos de relação entre o interior e o exterior mediados pela predação, o que explica a assertiva de Castro (1996) de que o animal é o protótipo extra-humano do outro. Mas isso deve significar que as metáforas não se fundam apenas em relação a um pensamento analógico, mas deste em relação recíproca com as condições naturais das quais os homens punçam a sobrevivência.

O universo da caça é constituído por forças materiais cujos processos de produção e reprodução não são controláveis pelos grupos humanos, o que talvez explique o grande número de tabus associados. Se o caráter ambivalente da caça está em ser simultaneamente dese- 
jável e perigosa, sua mística se confunde com a sua realidade. A caça, necessária e desejável, coloca os homens em confronto com forças que estão fora de seu controle, e que, portanto, podem ser perigosas como o são os inimigos. Em várias sociedades indígenas, inclusive as da família linguística Jê, a floresta (espaço exterior às aldeias e local da caça) é concebida como um mundo antissocial e perigoso (Vidal 1977), no qual podem ocorrer ao menos duas transformações perturbadoras: uma física entre predador e presa; e outra metafísica entre homem e animal.

No caso físico, os caçadores e os animais carnívoros são competidores entre si. Matam e se alimentam das mesmas presas. São, portanto, concorrentes. Não é então incomum observar em vários grupos indígenas da América do Sul, mesmo pertencentes a famílias linguísticas diferentes, tais como Jê, Tupi e Karib, a existência de uma temática constante: o jaguar aparecer como dono primordial do fogo e personagem central de várias mitologias, muitas das quais estudadas por Lévi-Strauss que considerou "o jaguar e o homem termos polares, cuja oposição é duplamente formulada na linguagem comum: um come comida crua; e, sobretudo, o jaguar come o homem, mas o homem não come o jaguar" (Lévi-Strauss 1996:87).

Animal caçador, o jaguar espelha ao homem a práxis da caça e, nesse jogo, ser predador ou presa depende da força e astucia do oponente, e bem sabiam os indígenas e os primeiros cronistas do Brasil. Quando um índio Guayaki sentenciou que se não tivesse êxito em seu preparo para se tornar caçador "seria ele mesmo a se tornar caça para este outro caçador que é o jaguar" (Clastres 1995:22), ele inverte a relação predador - presa e coloca o jaguar como o 'senhor da caça', como alguns cronistas reconheceram:

"Ha muitas onças, humas pretas, outras pardas, outras pintadas: he animal muito cruel, e feroz; accommettem os homens sobremaneira, e nem em árvores, principalmente se são grossas, lhes escapão; quando andão cevadas de carne não ha quem lhe espere principalmente de noite; matão logo muitas rezes juntas, desbaratam uma casa de gallinhas, huma manada de porcos, e basta darem uma unhada em 
hum homem, ou qualquer animal para o abrirem pelo meio [...]" (Cardim 1980:26).

O jaguar é o caçador. Inspira medo, respeito e representa, na caça, perigo e ameaça constantes; como na guerra os inimigos. Mundo da caça e mundo da guerra, caçadores e guerreiros, feras e inimigos parecem estar em analogia não apenas pelo exercício de um pensamento, mas também por decorrerem das experiências práticas. À série de transformações empíricas que levam o caçador a ser caça, a caça a ser guerra, a fera ser inimigo, corresponde também uma transformação matafisica entre homem e animal. Para a maioria dos grupos indígenas, inclusive os Jê - Kayapó (Vidal 1977), a floresta é este espaço perigoso porque nela os caçadores podem se transformar em presas e podem, também, se transformar em animais ou espíritos inimigos de seus parentes. Se na floresta, transformado em fera ou espírito inimigo, um homem pode então vir a devorar ou colocar em perigo seus parentes, é porque o jaguar, natureza indomada, hostil, feroz, caçadora e devoradora oferece o modelo do inimigo bravo.

Como mais um campo de fronteira entre o interior e o exterior, as relações entre homem e animal podem ser tomadas, como no caso das identidades e alteridades, como fluídas num misto de interesses e signos. Por isso, as transformações que levam de uns em outros nessa metafisica perspectiva só podem ser compreendidas como decorrentes tanto de uma série de homologias entre categorias intercambiáveis, como de uma prática venatória. Parecem comprovar essa assertiva as guerras e os rituais antropofágicos. Neles parece haver desde o início processos de domesticação dos poderes ferozes das alteridades. Quando Hans Staden já preso e amarrado era conduzido pelos Tupinambá ele ouviu: "[...] Xe rinbau ende: Tu és meo animal doméstico" (Araripe 1892:291). Fera amansada na captura ela passa por um primeiro processo de transformação, que devia incluir possibilidades de afinização, dado que "[...] entregavam os prisioneiros a guarda de uma mulher, que com ele vive" (Araripe 1892:351). Mas a domesticação da alteridade na predação canibal não estaria concluída caso a vítima 
não tivesse, mais uma vez, de passar por transformação ritual com correlatos claros com a práxis da caça. Ela atuava pela transformação do inimigo novamente em fera, animal abatido no terreiro, e na posterior inversão quando, na devoração, a fera passou a ser quem comia, como respondeu claramente Cunhambebe a uma interjeição de Hans Staden: "eu sou jaguar, e acho bom" (Araripe 1862:320; Castro 2002:255; Carvalho 2015:261). Está claro não só que a consumação de carne humana pode ser feita por esse outro matador de homens que é o jaguar, como inimigos e jaguares se traduzem uns nos outros.

Assim, do mesmo modo que o inimigo pode vir a ser jaguar, em sentido contrário o jaguar também pode tomar o lugar do inimigo. Quanto a isso, diferentes relatos dos Tupi do litoral são claros. A caça e morte ao jaguar podia em certos casos substituir com a mesma eficácia a morte do inimigo. Gabriel Soares de Souza (1964:288) relatou o modo ordinário de caçar o jaguar por meio de mundéus ou fojos e comentou que somente após ser aprisionada é que a fera podia ser morta a flechadas. Há casos relatados em que esses animais podiam, inclusive, serem mortos no terreiro, como aos inimigos, e deles "tomando nome e fazendo todas as cerimônias da antropofagia", tal como relata Cardim "[...] há índio que arremete com huma [onça], e tem mão nella e depois a mattam em terreiro como fazem aos contrários, tomando nome, e fazendo-lhes todas as cerimonias que fazem aos mesmos contrários" (1980:26).

As evidencias da analogia não podiam ser mais óbvias do que nesses grupos Tupi. Caso diferente parece ocorrer com os grupos Jê 'Cayapó' meridionais. Neste caso não encontramos a antropofagia, a não ser como alegoria da colonização. Mas sua ausência, como vimos, não distancia completamente esses grupos dos sistemas canibais. As evidencias históricas e etnográficas apontam para uma constante abertura para o mundo exterior mediada pela predação e incorporação de atributos e riquezas. Se a guerra nesses grupos representou a forma relacional e simbólica preferencial de contato com as alteridades, ela também teve correlatos claros com o mundo dos animais de caça. 
Em um grande número de grupos Jê, Kayapó-Gorotiré, Kayapó -Kubenkranken, Apinayé, Timbira e Xerente (Lévi-Strauss 1996:7178), o jaguar foi, como acima mencionado, o primeiro dono do fogo. Nesse tempo, ao invés dos homens era ele quem comia cozido e assava a caça que abatia. Apenas por meio de uma série de peripécias é que os humanos, nas diferentes versões do mito, enganam ou abatem a fera para dela roubarem o fogo. O protótipo do jaguar mitológico aparece aqui, como alhures, como resultado de uma condição prática e de uma inversão simbólica. Devorador de homens e animais ele é, na natureza, o que o caçador guerreiro é na sociedade, devorador de homens na guerra e de animais na caça.

Em uma série de outras mitologias de grupos Jê - Kayapó, além do fogo, as riquezas e virtudes tradicionais, tais como nomes bonitos, adornos plumários, bravura etc. foram tomados, roubados ou produzidos a partir da predação de animais como o jacaré, os peixes, a águia (Vidal 1977). E as analogias podem não parar por aí. Relatos da mitologia guerreira indicam que, ao matarem inimigos e os transportarem para aldeia, "amarraram os cadáveres pelas mãos e pés [...] como costumam levar a caça abatida do mato” (Luckesh 1976:189). O inimigo neste caso se transformou na caça abatida e domesticada; assim como o animal perseguido na caça pode vir a ser o inimigo perseguido em guerra. A perseverança dos indígenas em perseguirem e emboscarem suas presas foi relatada por um experiente sertanista do XVIII que atuava nas regiões dos atuais Triângulo Mineiro e sul de Goiás: "a 11 dias q" me segue o gentio Cayapó ao longe, queima todo o alojamto depois de seu sahir daquele lugar, hé inimigo q' não briga a peito descoberto, tendo-lhe feito mil enganos" (APM-CC-Cx 154-doc.21531). Nisto está claro que nas guerras as táticas foram semelhantes às da caça, o que por sua vez explica uma série de outras associações feitas por esses grupos entre guerra e caça: "ambas são lutas que conduzem a matança; e em ambas a vitória é melhor quanto mais forte for o oponente" (Luckesh 1976:89-90). Por isso, em relação à caçada o animal é inimigo, mas uma inversão mediada pela morte transforma o animal em parceiro. 
A suposição de que neste caso, como no dos grupos canibais, a natureza pode estar em relação ao inimigo é reforçada ainda por um conhecido ritual dos meninos púberes atacarem um ninho de marimbondo.

"O ataque a um ninho de marimbondo simboliza o ataque a uma aldeia inimiga. Aliás, os marimbondos e os índios inimigos são classificados sob uma mesma denominação: mẽkurê-djuoy,o que os índios traduzem por "inimigos" (Vidal 1977:126).

Em face desse espectro de fatos, parece certo que as analogias caça e guerra, inimigo e fera são tão nítidas entre os Jê como o são para os Tupi. Afinal, o que se percebe nas relações com suas alteridades (humanas e extra-humanas) é uma constante: no tempo mitológico, como na guerra histórica e na caça imemorial, estiveram onipresentes a predação e produção como processos sínteses de lógicas classificatórias e práxis material.

Assim, mesmo que para as áreas dos grupos Jê 'Cayapó' meridionais a relação entre guerra e caça não seja dada pela antropofagia, elas se fundam em 'trocas negativas' com o mundo exterior que podem nos colocar diante dos limites que se traçam para o impasse das urnas em áreas ocupadas por povos pertencentes à família dos Jê. Tanto para estes como para grupos Tupi a cerâmica recipiente, objeto prático de cocção de alimentos, se transforma em urna mortuária, objeto simbólico de enterramento dos parentes. De recipiente a urna, a transformação da cerâmica parece ser parte de uma práxis e cosmologia guerreira - caçadora.

\section{Caça, guerra e urnas: considerações finais (?)}

Se os indícios estiverem certos, as relações entre vivos e mortos estão para as mesmas categorias empíricas e classificatórias que opõem aliados - inimigos, homens - animais, qual seja: o das 'trocas negativas' entre interior - exterior. Se no caso da guerra e da caça a comunidade infringe perdas para os outros grupos humanos e para a natureza; a morte de um parente também é empiricamente uma 
perda, uma agressão que a natureza e/ou espíritos e/ou inimigos infligiram à comunidade.

Considerando desde o ponto de vista interno, mundo dos inimigos, mundo dos animais de caça e mundo dos mortos são mundos povoados por alteridades. Apesar da descontinuidade física que tornam essas alteridades diferentes (inimigos, jaguares e espíritos), o fundamento comum que se estabelece entre elas e o mundo interior, denominado ora de predação e ora de 'trocas negativas', tornam essas categorias intercambiáveis entre si. Não é então por acaso que em muitas sociedades indígenas o mundo dos mortos também contém perigos como os outros dois.

Em diferentes sistemas cosmológicos ameríndios, inclusive de grupos Jê - Kayapó, "o morto é temido; dele esperam-se atos de inimizade e sobre ele recai suspeita de, supostamente, ter provocado dor, doença, até morte de outros homens" (Luckesh 1976:208-209). Nos sofisticados rituais do sistema Jê - Bororo, por exemplo, a morte é o resultado da ação de uma entidade sobrenatural envolvida em todos os processos de criação e transformação - o bope; e no sistema Jê - Kayapó a morte é concebida a partir da atuação de forças e seres inimigos. Se os espíritos dos mortos podem se transformar em forças de intenção e atitudes destrutivas ao homem é porque se associam aos inimigos que em guerra também podem ferir e matar. Por esse esquema, se mortos são inimigos e inimigos são jaguares, logo os mortos são jaguares. E exemplos dessa transformação ocorre tanto no sistema cosmológico de grupos Jê, como Tupi.

No sistema Jê - Bororo, depois de morto, a alma passa a habitar o corpo de animais carnívoros como o jaguar e a jaguatirica. Além disso, parte desse sistema consistia no representante ritual do morto ter a tarefa de caçar um grande felino para assegurar a vingança do morto (Viertler 1999:119). Como a caça, a transformação do morto em jaguar também aparece em cosmologias de grupos Tupi. Clastres a encontrou entre os Guayaki, para os quais "os mortos são jaguares" e "um fantasma dos Aché tem a cabeça como a do jaguar" (1995:218). 
Inimigos, jaguares e espíritos dos mortos são parte de um mesmo grupo de transformações que levam do interior ao exterior, da sociedade à natureza, da aldeia à floresta, das identidades às alteridades. Se mortos são jaguares e inimigos, eles não são apenas excluídos da comunidade dos vivos, mas expulsos do mundo social da cultura e dos aliados, o que talvez explique o fato das urnas mortuárias, tanto nas áreas de ocupação histórica dos Tupinambá, Guarani e dos Jê 'Cayapó' meridionais, indicarem sepultamento no meio da floresta e nos espaços externos às estruturas habitacionais. Rejeitados para o lado da natureza, como jaguar e inimigo, o morto se transforma no outro.

Nesse caminho, urnas, como caça e guerra, são códigos que representam uma série de transformações mediadas pela predação e pela morte. Aí a cerâmica ocupa um papel ambíguo, pois igualmente transforma natureza em cultura e inversamente. Enquanto recipiente cerâmico, e mediada pelo fogo, ela fornece o processo de transformação do alimento natural em alimento cultural, e de modo análogo e inverso, enquanto urna mortuária, e mediada pelo enterramento, ela fornece o processo de transformação do vivo cultural em morto (sobre)natural.

Em face desses dados, e com base nas questões iniciais levantadas neste ensaio, os limites não se encontram nem em associar os sepultamentos em urnas com a antropofagia, nem nas oposições etnológicas Jê - Tupi. No primeiro desses casos, os dados aqui apresentados deslocam a urna dos sistemas antropofágicos em si, para situá-la nos sistemas de 'trocas negativas' e predação, cujo protótipo é a práxis e a cosmologia guerreira - caçadora. No segundo caso, desloca a atenção do binarismo dos sistemas centrípetos - centrífugos e evidencia a existência de sistemas híbridos que se ajustam melhor ao cenário histórico e etnográfico dos grupos Jê - 'Cayapó' meridionais, e a incidência de urnas em suas áreas históricas de ocupação. 


\section{Notas:}

1 Quando neste texto aparecer o termo 'Cayapó' com 'C' entre aspas simples, a referência é sua grafia na documentação histórica; ao passo que quando aparecer o termo Kayapó com ' $K$ ' a referência é sua grafia na etnografia conforme convenção da Associação Brasileira de Antropologia.

2 Embora a Arqueologia tradicional tenha aí indicado guias fósseis cerâmicos (decorados e não decorados) para classificar tradições, optamos por nos esquivar de suas classificações dado que as mesmas parecem refletir um entendimento das culturas e identidades como entidades monolíticas e fossilizadas. Em seu lugar, preferimos pensar as urnas em relação às informações da documentação histórica, cientes de que índios coloniais não são uma continuidade histórica com os povos pré-históricos porque as histórias, culturas e identidades são mutantes e cambiantes. 3 De acordo com a etnografia, esses vários grupos são inquestionavelmente filiados aos grupos dos Jê. O 'Cayapó' constitui uma língua homônima da família Jê do Tronco Macro-Jê, os Akroá, hoje extintos, falavam a língua 'Akuen', a mesma falada pelos Xakriabá e Xavante, e também considerada uma língua da família Jê do Tronco Macro-Jê.

4 Abreviatura aqui e doravante utilizada para a coleção de documentos publicados em várias edições pelo Arquivo Público do Estado de São Paulo com o título de Documentos Interessantes para a História e Costumes de São Paulo. Nas citações, a abreviatura D.I. é acompanhada do número do volume consultado, seguido do número de página; e nas referências constam as indicações completas da edição utilizada.

5 A política indigenista do período diferenciava os grupos indígenas em amigos e inimigos, normatizando o tipo de tratamento que deveriam receber os missionários e colonos. Os índios dos sertões foram invariavelmente associados à segunda categoria e a eles se voltou muito rapidamente uma política de extermínio e escravização. No caso dos Jê meridionais, desde 1730 já se tem declarada essa guerra.

6 Nos estudos atuais sobre as guerras entre grupos Tupi esse processo é concebido como 'predação familiarizante' (Fausto 2001). Nossa hipótese, consoante com a relativização do sistema centrípeto - centrifugo, é a de que os tipos de predação externa para produção interna podem ser estendidos aos grupos dos Jê meridionais 'Cayapó'.

\section{Referências:}

ALVES, Marcia A. 2013. "A Arqueologia no extremo oeste de Minas Gerais". Revista Espinhaço, 2(2):96-117.

1991. "Culturas ceramistas de São Paulo e Minas Gerais: estudo tecnotipologico". Revista do Museu de Arqueologia e Etnologia (1):71-96

CARVALHO, Silvia. 2015. Mitos e Práxis - por uma Antropologia marxiana. São Paulo: Terceira Margem. 
CARVALHO, Silvia. 1999. "A morte heróica do guerreiro". In CARVALHO, Silvia et al. (eds.): Rituais indígenas brasileiros, pp. 7-15. São Paulo: CPA. . 1983. "A cerâmica e os rituais antropofágicos". Revista de Antropologia, 26(1):39-52.

CLASTRES, Pierre. 1995. Crônica dos indios Guayaki. Rio de Janeiro: Edições 34.

CUNHA, M. C. \& CASTRO, E. V. 1985. "Vingança e temporalidade: os Tupinambá". Journal de la socièté dês americanistes, LXXI:191-208.

FAUSTO, Carlos. 2001. Inimigos fiéis: história, guerra e xamanismo na Amazônia. São Paulo: EDUSP.

GODOY, Manuel P. 1974. Contribuição à história natural e geral de Pirassununga. Pirassununga: Prefeitura de Pirassununga.

GORDON, Cesar. 2006. Economia selvagem - ritual e mercadoria entre os Xikrin Mebêngôkre. São Paulo: EdUNESP/ISA.

LEA, Vanessa. 2012. Riquezas Intangiveis de Pessoas Partiveis: Os Mebengokre (Kayapó) do Brasil Central. São Paulo: EdUSP.

LÉVI-STRAUSS, Claude. 1996. Mitológicas - Lo crudo y lo cocido. México: Fondo de Cultura Económica.

LÉVI-STRAUSS, C. \& ERIBON, Didier. 1990. De perto e de longe. Rio de Janeiro: Nova Fronteira.

LUCKESCH, Anton. 1976. Mito e vida dos indios Cayapós. São Paulo: Pioneira/EDUSP.

MAGALHÃES, Wagner. 2015. Estudo arqueométrico dos sítios arqueológicos Inhazinha e Rodrigues Furtado, município de Perdizes/MG. Dissertação de Mestrado. São Paulo: USP.

MENGET, Patrick. 1993. "Notas sobre as cabeças Munduruku". In CASTRO, E. V. \& CUNHA, M. (eds): Amazônia: etnologia e história indígena, pp. 311-322. São Pulo: NHII.

MANO, Marcel. 2011. "Contato, guerra e paz: problemas de tempo, mito e história”. Politica $\mathbb{E}$ Trabalho, 34(1):193-212.

METRAUX, Alfred. 1979. A religião dos tupinambás. São Paulo: Nacional/EDUSP.

MONTEIRO, John. 1994. Negros da terra - bandeirantes e indios na formação de São Paulo. São Paulo: Cia das Letras.

NEME, Mario. 1969. "Dados para a história dos índios Caiapó”. Anais do Museu Paulista, 23:101-147.

PEREIRA, M. A. et al. 1982. "Uma igaçaba de Capivari”. Publicação do Museu Municipal de Paulinia, (21):1-14.

SILVA, Cláudio S. 2015. História Indígena, Arqueológico e Patrimônio Cultural Triângulo Mineiro-MG. Trabalho de Conclusão de Curso. Ituiutaba: UFU.

SCHADEN, Egon. 1954. "Os primitivos habitantes do território paulista". Revista de História, 8(18):396-411.

TURNER, Terence. 1992. "Os Mebengokre Kayapó: história e mudança social, de comunidades autônomas para a coexistência interétnica”. In CUN̉HA, M. (ed.): História dos indios no Brasil, pp. 311-338. São Paulo: Cia das Letras. 
VIDAL, Lux B. 2001. "O mapeamento simbólico das cores na sociedade indígena Kayapó-Xikrin do sudoeste do Pará”. In SILVA, A. L. \& FERREIRA, M. K. L. (eds): Antropologia, história e educação - a questão indígena na escola, pp. 209220. São Paulo: Global.

.1977. Morte e vida de uma sociedade indígena brasileira: os kayapó-xikrin do Rio Catete. São Paulo: HUCITEC.

VIERTLER, Renate B. 1999. "As implicações adaptativas do Funeral ao processo de mudança social entre os Bororo de Mato Grosso". In CARVALHO, S. M. et al. (eds): Rituais Indígenas brasileiros, pp. 118-129. São Paulo: CPA.

CASTRO, Eduardo V. 1986. Araweté - os deuses canibais. Rio de Janeiro: Zahar. . 1996. "Os pronomes cosmológicos e o perspectivismo ameríndio". Mana, 2(2):115-144.

. 2002. A inconstância da alma selvagem. São Paulo: Cosak \&Naif.

WAGLEY, Charles. 1976. "Xamanismo Tapirapé". In SCHADEN, E. (ed.): Leituras de Etnologia Brasileira, pp. 236-267. São Paulo: Nacional.

\section{Documentos manuscritos:}

AHE-GO-Livro 003 - Cartas e Ofícios de d. Luiz de Mascarenhas 1731-1751. Arquivo Histórico Estadual de Goiás. Manuscritos.

AHU-ACL-CU-008-cx.1-d.17. Carta do superintendente das minas de Goiás ao rei [d. João V] sobre as hostilidades dos índios [...]. Goiás, 02/09/1735. CMD/UnB.

AHU-ACL-CU-008-cx.2-d.179. Carta do [governador e capitão-general de São Paulo] d. Luis de Mascarenhas ao rei [d. João V] sobre as atrocidades praticadas pelo gentio Cayapó [...]. Vila Boa, 30/03/1742. CMD/UnB.

AHU-ACL-CU-008-cx.2-d.465. Carta do [governador e capitão-general de Goiás] d. Marcos Noronha ao rei [d. José] sobre aldeamento dos índios [...]. Vila Boa, 24/01/1751. CMD/UnB.

AHU-ACL-CU-008-Cx.20-d.1220. Oficio do [governador e capitão-general de Goiás] ao secretário de Estado [...] sobre os novos ataques dos índios [...]. Vila Boa, 30/05/1764. CMD/UnB.

APM-CC-Cx.154-d.21531. Carta de Ignácio Correia Pamplona a Rodrigo Jose de Menezes. Serra dos Pavoens, 05/05/1781. Arquivo Público Mineiro.

\section{Documentos impressos:}

ARARIPE, Tristão. 1892. "Relação verídica e sucinta dos uzos e costumes dos Tupinambás por Hans Staden”. Revista do Instituto Histórico e Geográfico Brasileiro, tomo: LV, parte 1:267-360. 
CAMPOS, Antônio. Pires. 1976. "Breve notícia do gentio bárbaro [...] 1723". In TAUNAY, A. (ed): Relatos sertanistas, pp. 181-200. São Paulo: Livraria Martins Editora

CARDIM, Fernão. 1980. Tratado da terra e gente do Brasil. Belo Horizonte/Itatiaia/ São Paulo: EDUSP.

D.I. - Documentos Interessantes para a história e costumes de São Paulo, 1913, vol.22. Publicação oficial do Arquivo Público do Estado de São Paulo. Tipografia Cardozo Filho.

OLIVEIRA, Machado de. 1861. "Os Cayapó, sua origem, descobrimento [...]". Revista do Instituto Histórico e Geográfico Brasileiro, tomo XXIV:491-524.

SOUZA, Gabriel S. de. 1964. "Tratado descritivo do Brazil em 1587". Boletim Geográfico, ano XXIII, n.182. Conselho Nacional de Geografia - IBGE.

PONTES, Hildebrando. 1978. História de Uberaba e a Civilização no Brasil Central. Uberaba: Academia de Letras do Triângulo Mineiro.

Abstract: The article has as its motto the historical descriptions of indigenous burials in ceramic urns and intends, from an anthropological reading of them, to associate them with the universe of negative or predatory exchanges that human groups maintain with the outer world of the alterities. Based on an ethnological approach with historical and ethnographic data, the article discusses and problematizes two assumptions. The hypothesis that the urns are related to the anthropophagic-warrior universe described by the chroniclers between the Tupinambá and Guarani; and the Tupi - Jê differentiation model centered on the centrifugal $\mathrm{x}$ centripetal dichotomy. For this, it presents burial in urns as a code within a broader group of transformations that lead, in different Amerindian societies, from the interior to the exterior, and whose translation processes are the result of both classificatory thinking and a venatory practice.

Keywords: Burial, Groups Jê - 'Cayapó', Identities and alterities, War and anthropophagy, Hunting praxis.

Recebido em Dezembro de 2019.

Aprovado em Fevereiro de 2020. 